\title{
ЗБЕРЕЖЕННЯ СПОЖИВНИХ ВЛАСТИВОСТЕЙ ПРОДОВОЛЬЧИХ ТОВАРІВ 3 КОНОПЕЛЬ
}

\author{
O. DOMBROVSKA, L. CHURSINA, V.KRAGLIK
}

Kherson national technical university

\section{PRESERVING THE CONSUMER PROPERTIES OF HEMP FOOD PRODUCTS}

\section{https://doi.org/10.36910/6775-2310-5283-2022-15-10}

Мета. вибір найбільш придатних видів упаковки конопляної олії для збереження ї̈ споживних властивостей.

Методика. Теоретичні дослідження в роботі вирішувалися за допомогою сучасних методик та методів аналізу, систематизації, узагальнення, порівняння, індукиії та дедукиї, а також з використанням загальнонаукового аналітичного методу.

Результати. У статті розглянуто унікальні споживні властивості продовольчих товарів з конопель, наведено приклади пакування для різних видів продовольчих товарів з конопель, коротко розглянуто існуючі шляхи збереження їх споживних властивостей. Доведена необхідність збереження лікарських властивостей харчової продукиї 3 конопель за рахунок використання сучасних видів упаковки, щуо широко застосовуються у фармачевтичній промисловості.

Наукова новизна. Найбільш придатною формою для лікарського застосування конопляної олії є сучасні види пакування лікарських препаратів, які дозволяють зберегти фізико-хімічні властивості продукту, відповідне дозування, агрегатний стан тощо $i$ широко використовуються у фармацевтичній промисловості. Вперше запропоновано для збереження лікарських властивостей фармацевтичної продукиї з конопель використовувати пакування у вигляді скляних затемнених ампул й спеціальних розчинних полімерних капсул для одноразового застосування необхідної лікарської дози продукту. Таке пакування забезпечує первинну якість харчової продукиії з конопель та збереженість ї̈ лікарських властивостей.

Практична значимість. Для забезпечення якості та збереження лікарських властивостей конопляної олії за міжнародними стандартами потрібно використовувати матеріали, дозволені до використання при виробництві первинної упаковки для фармачевтичних препаратів та продуктів харчової промисловості, а саме найбільш придатними видами упаковки є скляні затемнені ампули й спечіальні розчинні полімерні капсули для одноразового застосування необхідної лікарської дози продукту. 
Ключові слова: продовольчі товари з конопель, споживні властивості, конопляна олія, лікарські властивості, ненасичені жирні кислоти, процес окиснення, упаковка.

Постановка проблеми у загальному вигляді і її зв'язок з важливими науковими та практичними завданнями. Конопляна олія - це ефективні, абсолютно натуральні, корисні та смачні ліки від багатьох хвороб, які завдяки своєму складу оптимізують дію імунної системи людини. Регулярне вживання конопляної олії в їжу допомагає при лікуванні патологій і хвороб, викликаних збоєм гомеостазу обмінних речовин [1].

Олія 3 насіння конопель має всі захисні ефекти поживної речовини. Тому щоденні добавки цієї олії в харчовий раціон приносять користь порівняну 3 ефектом вакцини, завдяки чому можна стверджувати, що конопляна олія $\epsilon$ унікальним продовольчим товаром. Завдяки своїм лікувальним і поживним властивостям, конопляну олію було відомо ще в стародавньому Китаї. В наш час вона широко використовується в медицині. Лікувальна дія конопляної олії офіційно підтверджена безліччю наукових досліджень в усьому світі. Конопляна олія корисна для кожної людини й в будь-якому віці.

Олія 3 конопель, містить вітаміни А, B1, B2, B6, E, K, D та інші. Також до іï складу входять різні мікроелементи: мінерали цинку, кальцію, заліза, магнію, фосфору, калію та сірки, смола, холін, цукор, едестин, сапоніни й поліненасичені жирні кислоти - Омега-3 і Омега-6 (табл. 1), які необхідні людині для росту клітинних мембран. Останні дослідження довели наявність в конопляній олії каротину, хлорофілу й дубильних речовин. Хлорофіл речовина, що має протипухлинну дію. Саме вона надає конопляній олії зеленуватий відтінок [2].

Таблиця 1. Конопляна олія: хімічний склад на 100 г [3]

\begin{tabular}{|c|l|l|l|l|l|l|}
\hline Калорійність & Вітаміни & Кислоти & Білки & Жири & Вуглеводи & $\begin{array}{l}\text { Мікроеле- } \\
\text { менти }\end{array}$ \\
\hline 899 Ккал & В (1, 2, 5, 6, & Омега-6; & $0 \%$ & $99,9 \%$ & $0 \%$ & Магній; \\
& $9,12) ;$ & Омега -3. & & & & Кальцій; \\
& C; & & & & & Калій; \\
& E; & & & & & Залізо; \\
& K; & & & & & Цинк; \\
& F; & & & & & Иод; \\
& D. & & & & & Налізо; \\
& & & & & & Фосрій; \\
\hline
\end{tabular}


Але, не дивлячись на унікальні споживні властивості продовольчих товарів 3 конопель, а саме конопляної олії, іiі широкому застосуванню та використанню перешкоджає одна властивість, що і $є$ ії головним недоліком. Під час зберігання завдяки високому вмісту ненасичених жирних кислот конопляна олія не стійка до окиснення, при цьому ненасичені кислоти, які здатні очищувати організм людини від шкідливих впливів продуктів харчування, перетворюються в насичені. Субстратами цієї реакції в загальному вигляді $\epsilon$ взаємодія ліпідів з киснем повітря. Ліпіди є лімітуючим фактором, який зумовлює параметри технологічного процесу та терміни зберігання олієжирової сировини, рослинних олій і харчових продуктів. При цьому швидкість окиснення залежить від багатьох факторів: температури, світла, вмісту антиокислювачів [4]. Тому при застосуванні конопляної олії основним завданням $\epsilon$ збереженість ненасичених жирних кислот в неокисленому вигляді. Одним із шляхів збереження споживних властивостей конопляної олії $\epsilon$ застосування вакуумування й спеціальних способів пакування.

Аналіз останніх досліджень, у яких започатковано вирішення проблеми. Питання зі збільшення строку зберігання детально розглянуто в роботі Сови Н.А. [4]. В якій було застосовано для збереження властивостей конопляної олії саше-пакети. При цьому було розглянуто різні способи стабілізації олії з конопель. Одним із таких способів $є$ внесення екстрактів рослинної сировини, яка має антиоксидантні властивості, що дозволяє стабілізувати процес окиснення. Роботи Токаєва Е. С., Манукьяна Г. Г., Драгонюк О. А., Демидова I. М., Ayadi 0. та інших провідних вчених також присвячені питанню пошуку альтернативного джерела для затримки окислення ліпідів в оліях [5,6]. Але, застосування розглянутих фізикохімічних способів збереження якості конопляної олії не можуть бути використані для збереження лікарських і харчових властивостей у зв'язку зі зміною її хімічного складу. На нашу думку, найбільш екологічним способом збереження унікальних властивостей конопляної олії $€$ застосування специфічних видів упаковки, які використовуються у фармацевтичній промисловості. Тому в даній роботі проведемо аналіз збереження споживних властивостей конопляної олії за допомогою застосування різних видів упаковки.

Цілі статті. Метою статті $\epsilon$ вибір найбільш придатних способів упаковки конопляної олії для збереження іiї споживних властивостей. 
Об'єкт дослідження. Види упаковки конопляної олії.

Методи дослідження. Використано загальнонауковий аналітичний метод, метод систематизації, узагальнення, порівняльний.

Виклад основного матеріалу дослідження з повним обгрунтуванням отриманих наукових результатів. Останнім часом в Україні поступово повертається інтерес підприємців до переробки конопель у продовольчі товари й товари широкого вжитку. 3'являються нові інноваційні технології, а завдяки їм і новітні товари. Так сфера використання продукції з конопель досить велика - від продовольчих товарів і косметики до будівництва «екологічних осель» [7]. Тому вважаємо, що дану рослину можна назвати унікальним товаром, що має широкий спектр використання i неабияку практичну значимість для народного господарства. Особливого розповсюдження на полицях супермаркетів набув такий вид продовольчих товарів як конопляна олія.

Так, компанія «Richoil», пропонує споживачеві олію 3 конопель в скляній тарі різних видів (табл. 2) [8].

Таблиця 2. Характеристика продовольчих товарів 3 конопель компанії «Richoil» [8]

\begin{tabular}{|c|c|c|c|c|c|}
\hline $\begin{array}{c}\text { Вигляд } \\
\text { упаковки }\end{array}$ & Пакування & Фасування & $\begin{array}{c}\text { Енергетична } \\
\text { цінність }\end{array}$ & $\begin{array}{c}\text { Термін } \\
\text { придат- } \\
\text { ності }\end{array}$ & $\begin{array}{c}\text { Умови } \\
\text { зберігання }\end{array}$ \\
\hline 1 & 2 & 3 & 4 & 5 & 6 \\
\hline \multicolumn{6}{|c|}{ Борошно конопляне безглютенове } \\
\hline 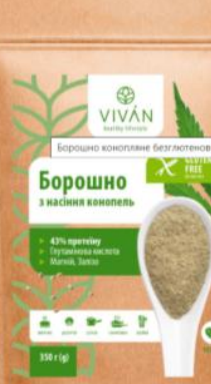 & $\begin{array}{c}\text { Дой-пак. Зип- } \\
\text { замок, } \\
\text { герметичне } \\
\text { пакування } \\
\text { Бар'єрність 100\% }\end{array}$ & 350 г & 381 кКал & $\begin{array}{c}14 \\
\text { місяців }\end{array}$ & $\begin{array}{c}\text { Зберігати за } \\
\text { температури } \\
\text { до плюс } \\
35^{\circ} \mathrm{C} \text { при } \\
\text { відносній } \\
\text { вологості } \\
\text { повітря не } \\
\text { більше } 75 \%\end{array}$ \\
\hline
\end{tabular}


Товарознавчий вісник. - 2022. - Випуск 15.

\begin{tabular}{|c|c|c|c|c|c|}
\hline 1 & 2 & 3 & 4 & 5 & 6 \\
\hline \multicolumn{6}{|c|}{ Клітковина з насіння конопель } \\
\hline 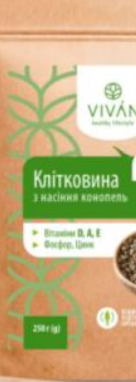 & $\begin{array}{c}\text { Дой-пак. Зип-замок, } \\
\text { герметичне пакування } \\
\text { Бар'єрність 100\% }\end{array}$ & 250 г & 245 ккал & $\begin{array}{c}14 \\
\text { місяців }\end{array}$ & $\begin{array}{c}\text { Зберігати за } \\
\text { температури } \\
\text { до плюс } \\
35{ }^{\circ} \mathrm{C} \text { при } \\
\text { відносній } \\
\text { вологості } \\
\text { повітря не } \\
\text { більше } 75 \%\end{array}$ \\
\hline \multicolumn{6}{|c|}{ Олія конопляна } \\
\hline & $\begin{array}{c}\text { Скляна затемнена } \\
\text { пляшка з закруткою. } \\
\text { Бар’єрність 100\% }\end{array}$ & 250 мл & 899 ккал & $\begin{array}{c}14 \\
\text { місяців }\end{array}$ & $\begin{array}{c}\text { Зберігати в } \\
\text { закритих і } \\
\text { затемнених } \\
\text { приміщеннях } \\
\text { за } \\
\text { температури } \\
\text { від } 0^{\circ} \mathrm{C} \text { до } \\
\text { плюс } 30^{\circ}\end{array}$ \\
\hline \multicolumn{6}{|c|}{ Олія конопляна з базиліком } \\
\hline 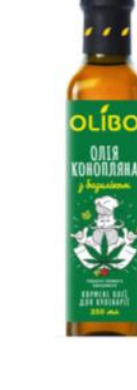 & $\begin{array}{c}\text { Скляна затемнена } \\
\text { пляшка з закруткою. } \\
\text { Бар'єрність 100\% }\end{array}$ & 250 мл & 898 ккал & $\begin{array}{c}14 \\
\text { місяців }\end{array}$ & $\begin{array}{c}\text { Зберігати в } \\
\text { закритих і } \\
\text { затемнених } \\
\text { приміщеннях } \\
\text { за } \\
\text { температури } \\
\text { від 0 С до } \\
\text { плюс } 30^{\circ}\end{array}$ \\
\hline
\end{tabular}

Аналіз наведених в таблиці 2 зразків продовольчих товарів 3 конопель обмежується лише вже відомими й широко розповсюдженими видами пакування. Для того, щоб забезпечити комплекс корисних властивостей упаковки для продовольчих товарів 3 конопель, необхідні переоцінка i трансформація вже існуючих пакувальних рішень.

Дані таблиці 2 свідчать, що українські виробники, як правило, для фасування конопляної олії використовують скляну затемнену тару. Термін придатності такого продукту становить в закритому вигляді 14 місяців. Але виробники зазвичай не вказують скільки даний товар буде зберігати свої цілющі властивості після відкриття пляшки. 
На нашу думку, найбільшого застосування та використання будуть мати лікарські форми конопляних олій. Тому найбільш придатною формою для лікарського застосування конопляної харчової продукції $є$ сучасні види упаковки лікарських препаратів, які дозволяють зберегти фізико-хімічні властивості продукту, відповідне дозування, агрегатний стан тощо і широко використовуються у фармацевтичній промисловості [9].

Як показує досвід країн Європейського Союзу, для збереження лікарських властивостей фармацевтичної продукції 3 конопель найбільш придатними видами упаковки $\epsilon$ скляні затемнені ампули й спеціальні розчинні полімерні капсули для одноразового застосування необхідної лікарської дози продукту [9].

Така упаковка забезпечує первинну якість харчової продукції з конопель та збереженість ії лікарських властивостей. Оскільки упаковка слугує, в першу чергу, для збереження початкових властивостей i характеристик продовольчих товарів, а також захищає їх від шкідливого впливу зовнішніх факторів, тому до вибору пакування треба ретельно підходити з урахуванням всіх специфічних властивостей кінцевого продукту. Наразі в країнах Західної Європи, в США і навіть в Україні зараз приділяється значна увага розгляду питання «функціональне» та «еко» пакування з використанням інноваційних технологій та матеріалів, що створюють додаткові споживчі зручності і не тільки зберігають початкові характеристики продукту, а й зберігають цінні харчових властивості товару на протязі тривалого часу [10].

Висновки та перспективи подальших досліджень. Таким чином, для забезпечення якості лікарських властивостей продовольчих товарів 3 конопель потрібно використовувати матеріали для пакування, що дозволені до використання при виробництві первинної упаковки для фармацевтичних препаратів та продуктів харчової промисловості, які відповідають вимогам Європейських директив та FDA [11,12]. Також необхідно проводити вивчення стабільності готових лікарських засобів в обраній упаковці та збереженості їх агрегатного стану, фізико-хімічних властивостей та якісного складу продукту. Для випуску новітніх конкурентоспроможних препаратів потрібно не лише ретельно підбирати вид і матеріал упаковки, а й постійно вдосконалювати й модернізувати лінії упаковок за європейськими стандартами з використанням світових тенденцій у виробництві пакувальних матеріалів. 


\section{Список використаних джерел}

1. Конопляна олія в боротьбі 3 хворобами. URL: https://perlynapolissya.com/konoplyanoe-maslo-v-borbe-s-boleznyami

2. Молоді коноплі - королева серед зелених продуктів. URL: https://wwwcannadorra-ru.translate.goog/zhurnal-o-konople/konoplyanye-produkty/576-molodayakonoplya-koroleva-sredi-zelenykh-

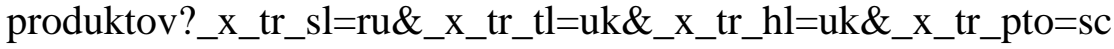

3. Конопляне масло: склад, лікувальні властивості, як його зберігати? URL: https://w2w.com.ua/konopliane-maslo-sklad-likyvalni-vlastivosti-dlia-jinok-y-tomy-chisli-iberemnnyh-i-dlia-cholovikiv-protipokazannia-a-takoj-dopomagaie-vid-p/ (дата звернення 20.05.2019).

4. Сова Н. А. Технологія комплексної переробки насіння промислових конопель: дис. ... канд. техн. наук: спец. 05.18.02. Технологія зернових, бобових, круп'яних продуктів і комбікормів, олійних і луб'яних культур. Херсон, 2019. 331 с.

5. Стабілізація до окиснення ліпідів арахісово-лляного купажу. 2014.

6. Ayadi, M. Physico-chemical change and heat stability of extra virgin olive oils flavoured by selected Tunisian aromatic plants [Text] / M. Ayadi, N. Kamoun, H. Attia // Food and Chemical Toxicology. 2009. Vol. 47, Iss. 10. P. 2613-2619. doi:10.1016/j.fct.2009.07.024.

7. Зелена книга. Ринок технічних конопель. URL: https://regulation.gov.ua/book/165zelena-kniga-rinok-tehnicnih-konopel

8. https://richoil.ua/uk/magazin/

9. Сучасні види упаковки готових лікарських засобів. URL: https://www.pephemp.com/storage/app/media/price/price.pdf?updated_10_12_20

10. Особливості пакування харчових продуктів в MГC. URL: http://dspace.nuft.edu.ua/bitstream/123456789/11351/1/Skooophpvmgs.pdf

11. Pharmaceutical Packaging Professionals. URL: www.pharmpackpro.com

12. PCI Completes Acquisition of Pharmaceutical Packaging Professionals. URL: http://pciservices.com/pci-completes-acquisition-pharmaceutical-packaging-professionals/

\section{References}

1. Konopliana oliia $\mathrm{v}$ borotbi $\mathrm{z}$ khvorobamy. URL: https://perlynapolissya.com/konoplyanoe-maslo-v-borbe-s-boleznyami

2. Molodi konopli - koroleva sered zelenykh produktiv. URL: https://wwwcannadorra-ru.translate.goog/zhurnal-o-konople/konoplyanye-produkty/576-molodayakonoplya-koroleva-sredi-zelenykhproduktov?_x_tr_sl=ru\&\&_x_tr_tl=uk\&_x_tr_hl=uk\&_x_tr_pto=sc

3. Konopliane maslo: sklad, likuvalni vlastyvosti, yak yoho zberihaty? URL: https://w2w.com.ua/konopliane-maslo-sklad-likyvalni-vlastivosti-dlia-jinok-y-tomy-chisli-iberemnnyh-i-dlia-cholovikiv-protipokazannia-a-takoj-dopomagaie-vid-p/ (data zvernennia 20.05.2019).

4. Sova N. A. Tekhnolohiia kompleksnoi pererobky nasinnia promyslovykh konopel: dys. ... kand. tekhn. nauk: spets. 05.18.02. Tekhnolohiia zernovykh, bobovykh, krupianykh produktiv i kombikormiv, oliinykh i lubianykh kultur. Kherson, 2019. $331 \mathrm{s.}$

5. Stabilizatsiia do okysnennia lipidiv arakhisovo-llianoho kupazhu. 2014.

6. Ayadi, M. Physico-chemical change and heat stability of extra virgin olive oils flavoured by selected Tunisian aromatic plants [Text] / M. Ayadi, N. Kamoun, H. Attia // Food and 
Chemical Toxicology. - 2009. - Vol. 47, Iss. $10 . \quad-\quad$ R. 2613-2619. doi:10.1016/j.fct.2009.07.024.

7. Zelena knyha. Rynok tekhnichnykh konopel. URL: https://regulation.gov.ua/book/165zelena-kniga-rinok-tehnicnih-konopel

8. https://richoil.ua/uk/magazin/

9. Suchasni vydy upakovky hotovykh likarskykh zasobiv. O.K. Yamniuk, S.M. Hureieva. URL: https://www.pephemp.com/storage/app/media/price/price.pdf?updated_10_12_20

10. Osoblyvosti pakuvannia kharchovykh produktiv v MHS. O.O. Havva, M.A. Maslo. URL: http://dspace.nuft.edu.ua/bitstream/123456789/11351/1/Skooophpvmgs.pdf

11. Pharmaceutical Packaging Professionals. URL: www.pharmpackpro.com

12. PCI Completes Acquisition of Pharmaceutical Packaging Professionals. URL: http://pciservices.com/pci-completes-acquisition-pharmaceutical-packaging-professionals/

Purpose. choosing the most appropriate types of hemp oil packaging to preserve its consumer properties.

Methodology. Theoretical research in the work was solved using modern techniques and methods of analysis, systematization, generalization, comparison, induction and deduction, as well as using analytical general scientific method.

Findings. The article considers unique consumer properties of hemp foodstuffs, gives examples of packaging for different kinds of hemp foodstuffs, briefly examines the existing ways of preserving their consumer properties. The necessity of preserving medicinal properties of hemp food products through the use of modern types of packaging widely used in the pharmaceutical industry is proved.

Originality. The most suitable form for medicinal application of hemp oil is modern kinds of package which allow to save physical and chemical properties of the product, corresponding dosage, aggregate state, etc. and are widely used in pharmaceutical industry.

For the first time it was proposed to use packaging in the form of glass darkened ampoules and special soluble polymeric capsules for a single application of the required dosage of the product to preserve the medicinal properties of pharmaceutical products from hemp. Such packaging ensures the primary quality of hemp food products and preservation of their medicinal properties.

The practical value. To ensure the quality and preservation of medicinal properties of hemp oil according to international standards, it is necessary to use materials approved for use in the production of primary packaging for pharmaceuticals and food products, and the most suitable types of packaging are glass darkened ampoules and special soluble polymeric capsules for single application of the required medicinal dose of the product.

Keywords: hemp food products, consumer properties, hemp oil, medicinal properties, unsaturated fatty acids, oxidation process, packaging.

Рекомендовано до публікаиії доктором технічних наук, професором Херсонського НТУ Тіхосовою Г.А. Дата надходження в редакиію 15.01.2022 p. 